\title{
Long term virological, immunological and mortality outcomes in a cohort of HIV-infected female sex workers treated with highly active antiretroviral therapy in Africa
}

Charlotte Huet ${ }^{1}$, Abdoulaye Ouedraogo ${ }^{1}$, Issouf Konaté ${ }^{1}$, Isidore Traore ${ }^{1}$, François Rouet ${ }^{1}$, Antoinette Kaboré ${ }^{1}$ Anselme Sanon ${ }^{1}$, Philippe Mayaud ${ }^{2 *}$, Philippe Van de Perre ${ }^{3}$ and Nicolas Nagot $^{3}$

\begin{abstract}
Background: Concerns have been raised that marginalised populations may not achieve adequate compliance to antiretroviral therapy. Our objective was to describe the long-term virological, immunological and mortality outcomes of providing highly active antiretroviral therapy (HAART) with strong adherence support to HIV-infected female sex workers (FSWs) in Burkina Faso and contrast outcomes with those obtained in a cohort of regular HIVinfected women.
\end{abstract}

Methods: Prospective study of FSWs and non-FSWs initiated on HAART between August 2004 and October 2007. Patients were followed monthly for drug adherence (interview and pill count), and at 6-monthly intervals for monitoring CD4 counts and HIV-1 plasma viral loads (PVLs) and clinical events.

Results: 95 women, including 47 FSWs, were followed for a median of 32 months (interquartile range [IQR], 20-41).

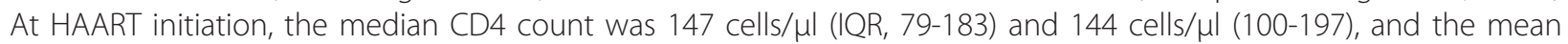
PVLs were $4.94 \log _{10}$ copies/ml (95\% confidence interval [Cl], 4.70-5.18) and $5.15 \log _{10}$ copies/ml (4.97-5.33), in FSWs and non-FSWs, respectively. Four FSWs died during follow-up (mortality rate: 1.7 per 100 person-years) and none among other women. At 36 months, the median CD4 count increase was 230 cells/ $\mu$ (IQR, 90-400) in FSWs vs. 284 cells/ $\mathrm{Hl}$ (193-420) in non-FSWs; PVL was undetectable in 81.8\% (95\% Cl, 59.7-94.8) of FSWs vs. 100\% (83.9-100) of non-FSWs; and high adherence to HAART (> 95\% pills taken) was reported by $83.3 \%$ (95\% Cl, 67.2-93.6), 92.1\% (95\% Cl, 78.6-98.3), and 100\% (95\% Cl, 54.1-100) of FSWs at 6, 12, and 36 months after HAART initiation, respectively, with no statistical difference compared to the pattern observed among non-FSWs.

Conclusions: Clinical and biological benefits of HAART can be maintained over the long term among FSWs in Africa and could also lead to important public health benefits.

\section{Background}

Highly active antiretroviral therapy (HAART) programmes are now widely available in Africa. High and sustainable efficacy, similar to that achieved in industrialised settings, can be obtained despite frequent treatment initiation at a later stage of HIV disease progression [1-4]. Beside individual benefits, HAART also has potential public health benefits [5], through

\footnotetext{
* Correspondence: philippe.mayaud@lshtm.ac.uk

${ }^{2}$ London School of Hygiene \& Tropical Medicine (LSHTM), London, UK Full list of author information is available at the end of the article
}

reduced HIV genital shedding [6] and decreased transmission [7-10], which forms the core hypothesis of the much debated 'Treatment as Prevention' concept [11].

Professional female sex workers (FSWs), alongside less visible groups involved in part-time transactional sex such as bar workers, mobile fruit sellers [12], represent an important core HIV transmitter group that plays a central role in the dynamics of HIV transmission in West Africa [13,14]. The estimated population attributable fraction for prevalent HIV infection related to sexual contact with FSWs was $84 \%$ and $76 \%$ in the male adult

\section{C) Biomed Central}


populations of Accra (Ghana) and Cotonou (Benin) in the early 2000's, respectively [15]. Several HIV prevention intervention programmes have targeted high-risk populations by providing access to condoms, promoting behaviour change and offering sexually transmitted infections (STI) care [16,17], but few programmes have specifically provided HAART, because of the logistical difficulty of implementing complex programmes in these often marginalised and hard-to-reach populations, with perceived poor social or familial support for drug adherence. We hypothesised that this group would have a similar adherence to HAART as non-FSWs, and consequently would have similar treatment outcomes, provided sufficient support is supplied by health care services and the community.

The objectives of the research were to measure the long term virological, immunological and clinical efficacy of HAART in a cohort of FSWs in Burkina Faso and contrast these treatment outcomes with those obtained among in a contemporary cohort of non-FSW HIV-positive women taking HAART.

\section{Methods}

\section{Setting and patients}

We conducted a prospective observational study nested within the Yerelon open cohort of high-risk women (ANRS 1222) described previously [18]. Since 1998, the Yerelon programme has been offering confidential HIV prevention and care services to professional and nonprofessional FSWs living in Bobo-Dioulasso, Burkina Faso [12]. Participants were recruited between December 2003 and January 2005 for the first enrolment period, and between March 2007 and September 2007 for the second enrolment period. Potential participants were recruited through a network of peer-educators, then enrolled if eligible and consenting to study procedures and followed up at a dedicated clinic located within a public health facility. All participants benefited from frequent and regular peer-led information and education sessions on condom use, HIV and STI prevention, and HIV disease progression. Between August 2004 and January 2005, women from local organizations of people living with HIV/AIDS (PLWHA) and from the University Hospital in Bobo-Dioulasso were recruited additionally to participate in two trials of Herpes Simplex Virus (HSV) suppressive therapy [6,19], resulting in both FSWs and non-FSWs to form the cohort population. Since April 2004, HAART has been provided to HIVinfected participants who were or became eligible according to the WHO guidelines for HIV care [20]. At that date, 23 women from local PLWHA organizations and the University Hospital were already on HAART.

The Yerelon Cohort Research Programme has been approved by the Centre Muraz institutional review board, and the ethics committees of the Burkina Faso Ministry of Health and the London School of Hygiene \& Tropical Medicine.

\section{Study procedures}

Cohort participants were invited to attend the study clinic every four months for routine follow-up visits, including collection of socio-demographic, behavioural, clinical and biological data. Study participants who started HAART were followed at closer intervals: weekly during the first two weeks, and monthly during the whole follow-up for clinical examination, detection of drug adverse effects and counselling on adherence. CD4 + cell count and HIV-1 PVL were measured every six months. For patients who missed follow-up visits, telephone calls and home visits were made by a team of peer-educators and social workers. Information on cause of death was obtained through hospital files and interviews of relatives during home visits or telephone calls. Prevention of opportunistic infections using cotrimoxazole was systematically offered to all patients according to WHO 2006 guidelines [21].

\section{Antiretroviral therapy}

HAART initiation and monitoring followed national guidelines adapted from WHO [20]. Accordingly, women with CD $4+$ count $\leq 200$ cells $/ \mu$, WHO AIDS stage IV, or WHO stage III and CD4 count $\leq 350$ cells/ $\mu \mathrm{l}$, were eligible for HAART. The first line treatment regimen consisted of triple-drug combination including two nucleoside reverse transcriptase inhibitors (NRTIs) (zidovudine [AZT] or stavudine [d4T] in case of anaemia, and lamivudine [3TC]) with either (i) a nonnucleoside reverse transcriptase inhibitor (NNRTI), preferably efavirenz for women infected with HIV-1 or women infected with both HIV-1 and HIV-2 with effective contraception, or nevirapine for women not desiring contraception, or (ii) a protease inhibitor (PI) (indinavir plus ritonavir or nelfinavir), which was used also for second line treatment.

Counselling on HAART adherence and adverse events was provided by the physician and the drug dispensing nurse each month. When adherence was not optimal, clinical psychologists provided additional counselling and discussed obstacles to adherence. Peer-educators regularly organised group information and education sessions on treatment adherence at the study clinic. Adherence counselling sessions started before HAART initiation and continued throughout the study period. The adherence procedures and support measures were the same for all participants. The need for this multidisciplinary approach to adherence support was identified through qualitative research carried out at the onset of the Yerelon project (unpublished). Attendance to 
adherence sessions was voluntary and no compensation was provided to participants.

\section{Biological measurements}

HIV seropositivity was determined either with two complementary enzyme-linked immunosorbent assays (ELISAs) [22] or using a rapid testing strategy with Determine (Abbott), followed by Genie II (BioRad), as recommended by WHO [23], with an ELISA confirmatory testing for discrepant results. CD4+ count was measured using FACScan (Becton Dickinson, Flatlands, NJ) and plasma HIV-1 RNA was quantified using a realtime PCR assay (Generic HIV Viral Load ${ }^{\circledR}$, Biocentric, Bandol, France), with a lower limit of detection of 300 [2.48 $\log _{10}$ ] copies/ml [24]. HSV-2 serology was performed using a specific IgG2 ELISA (Kalon Biologicals) with high sensitivity and specificity in African serum samples [25].

Data on adverse events were obtained from visit forms and from routine and acute laboratory investigations, including haemograms, kidney and liver functions. Laboratory tests were planned at 2, 4, and 16 weeks, then every 4 months and when clinically indicated. Serious adverse events were defined based on the ANRS scaling system [26].

\section{Statistical analysis}

Outcomes for HAART efficacy in this study included: (i) mortality rates; (ii) median values for $\mathrm{CD} 4+\mathrm{T}$-cell count and CD4+ T-cell gain at 6,12, 24, and 36 months after HAART initiation; (iii) virological success, defined as two consecutive samples with undetectable HIV-1 PVL (<300 copies/ml) after HAART initiation; (iv) primary virological failure, defined as persistence of detectable HIV-1 PVL 6 months after HAART initiation; and (v) secondary virological failure, defined by at least one plasma sample with detectable HIV-1 RNA, not due to HAART interruption, after initial virological success.

Participants were considered lost to follow-up if their last contact with the study team was at least 6 months prior to the study end, i.e., if no information on vital status could be recorded between 30 April and 30 October 2007.

Mortality probability was estimated using the KaplanMeier method. Undetectable PVLs were allocated a value equal to half the detection threshold, and plasma HIV-1 RNA copies/ml were $\log _{10}$ transformed to normalise their distribution.

HAART adherence was assessed every month by pill count and expressed as the mean of the proportion of pills taken to pills that should have been taken, for each antiretroviral drug during the previous 30 days.

The statistical analysis was conducted using Stata version 9.0 (Stata Corp, Texas). Univariate comparisons were performed using the Chi-2 test for qualitative outcomes and the Student t-test for quantitative outcomes. The log-rank test was used to assess unadjusted differences between the survival KaplanMeier curves.

\section{Results}

\section{Characteristics of participants at HAART initiation}

Forty seven FSWs and 48 non-FSWs started antiretroviral treatment and were followed up between August 2004 and October 2007 (Figure 1). Characteristics of the 95 participants at HAART initiation are detailed in Table 1. All women were infected with HIV-1, and one patient was infected with HIV-1 and HIV-2. The median age was 33 years (interquartile range [IQR], 28-39). Among FSWs, the median number of years of transactional sex was 8 (IQR, 5-13) and the median number of clients per week was 2 (IQR, 0-2). Twice as many FSWs than non-FSWs admitted recent alcohol consumption $(64 \%$ vs. $33 \%, P=0.003)$. At HAART initiation, the median CD4+ count was 147 cells/ $\mu$ l (IQR, 79-183) and 144 (100-197) in FSWs and non-FSWs, respectively, and the mean PVLs were $4.94 \log _{10}$ copies/ml (95\% confidence interval [CI], 4.70-5.18) and 5.15 (4.97-5.33), respectively $(P=0.16) .70 \%$ of FSWs and $69 \%$ of non-FSWs were at WHO clinical stages III/IV.

\section{Antiretroviral treatment and side effects}

The HAART regimen consisted of two NRTIs plus one NNRTI in 92 (97\%) patients, and two NRTIs plus one PI in 3 (3\%) patients (Table 1). During follow-up, six (6\%) women experienced a serious adverse event: one woman had to be switched from efavirenz to nevirapine because of central neurological disturbances, one woman stopped $\mathrm{d} 4 \mathrm{~T}$ and switched to AZT because of peripheral neuropathy, and four women were switched from AZT to d4T because of severe anaemia. Moreover, $17(18 \%)$ women were switched from efavirenz to nevirapine: 14 who became pregnant, and 3 who wanted to become pregnant.

\section{Adherence}

The median follow-up of all participants was 32 months (IQR, 20-41 months), yielding 233 person-years of observation. The proportion of FSWs with $\geq 95 \%$ adherence to their antiretroviral regimen by pill count was 83.3\% (95\% CI, 67.2-93.6), 92.1\% (95\% CI, 78.6-98.3), and $100 \%$ (95\% CI, 54.1-100) 6, 12, and 36 months after HAART initiation, respectively. These values were not statistically different from the corresponding proportions for non-FSWs which were 95.3\% (95\% CI, 84.2-99.4, $P=$ 0.08), 92.7\% (95\% CI, 80.1-98.5), and 100\% (95\% CI, 63.1-100). 


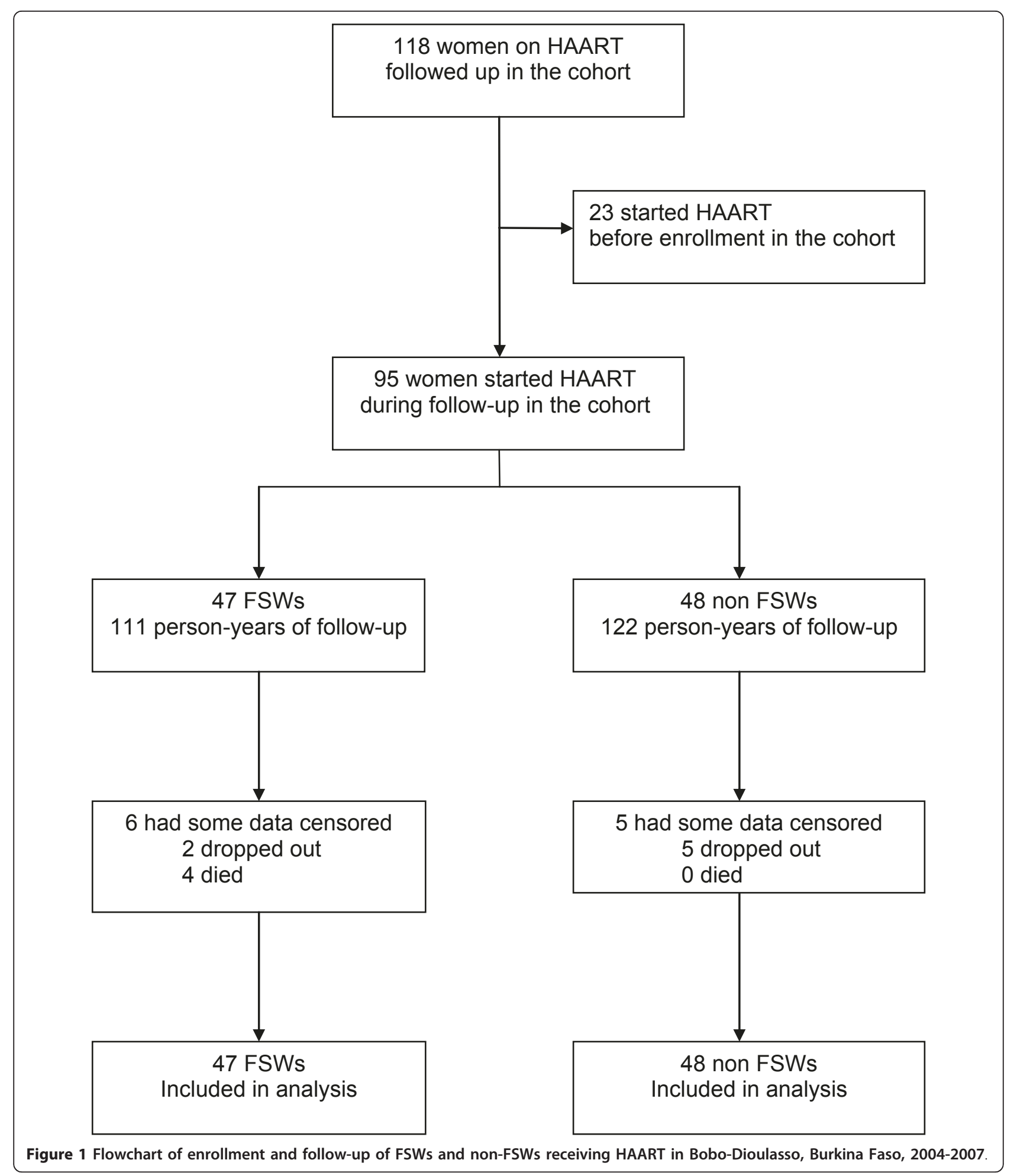

\section{Mortality}

Seven women (including two FSWs) were lost during follow-up and four FSWs died (mortality rate: 1.7 per 100 person-years) versus none in the non-FSW group. Among FSWs, the cumulative probability of death after
HAART initiation was 0.06 (95\% CI, 0.02-0.18) at 12 months and 0.09 (95\% CI, 0.03-0.22) at 36 months, respectively, which was significantly different from mortality rates observed in non-FSWs (logrank test $=0.04$, Figure 2). The median time between HAART initiation 
Table 1 Characteristics of female sex workers (FSWs) and non-FSWs at their HAART initiation visit in Bobo-Dioulasso, Burkina Faso, 2004-2007

\begin{tabular}{|c|c|c|c|c|c|}
\hline \multirow[t]{2}{*}{ Characteristics } & \multicolumn{2}{|c|}{$\begin{array}{l}\text { FSWs } \\
(\mathrm{N}=47)\end{array}$} & \multicolumn{2}{|c|}{$\begin{array}{l}\text { Non-FSWs } \\
(\mathrm{N}=48)\end{array}$} & \multirow[t]{2}{*}{$P$-value } \\
\hline & $\mathrm{n}$ & $(\%)$ & $\mathrm{n}$ & (\%) & \\
\hline \multicolumn{6}{|l|}{ Socio-demographic characteristics } \\
\hline Age, median (IQR), years & 31 & $(27,35)$ & 35 & $(31,41)$ & 0.01 \\
\hline Education $(\mathrm{n}=89)$ & & & & & 0.86 \\
\hline Secondary & 10 & (22) & 11 & (26) & \\
\hline Primary & 15 & (32) & 12 & (28) & \\
\hline Illiterate & 21 & (46) & 20 & (46) & \\
\hline Age at first sex, median (IQR), years $(n=89)$ & 16 & $(15,17)$ & 16 & $(15,18)$ & 0.98 \\
\hline Married $(n=89)$ & 10 & (22) & 10 & (23) & 0.86 \\
\hline Trip outside the city last 12 months $(n=89)$ & 24 & (52) & 20 & (47) & 0.59 \\
\hline \multicolumn{6}{|l|}{ Behavioural characteristics } \\
\hline Alcohol use in the last week & 30 & (64) & 16 & (33) & 0.003 \\
\hline Has a steady sexual partner at enrolment $(n=88)$ & 37 & $(80)$ & 21 & (50) & 0.003 \\
\hline No. sexual intercourses in the last week, median (IQR), $(n=88)$ & 2 & $(0-3)$ & 0 & $(0-1)$ & $<0.001$ \\
\hline Always uses condoms with unknown casual sexual partners $(n=88)$ & 35 & (76) & 31 & (74) & 0.81 \\
\hline Always uses condoms with known sexual partners $(n=88)$ & 25 & (54) & 30 & (71) & 0.10 \\
\hline Always uses condoms with steady sexual partner(s) $(n=31)$ & 3 & $(13)$ & 3 & (38) & 0.16 \\
\hline \multicolumn{6}{|l|}{ Clinical and biological characteristics } \\
\hline Body mass index, median (IQR), kg/m² & 20.7 & $(18.4,23.6)$ & 19.0 & $(17.4,21.8)$ & 0.08 \\
\hline WHO clinical stages $(n=88)^{*}$ & & & & & 0.94 \\
\hline Stage I & 4 & (8) & 4 & (9) & \\
\hline Stage ॥ & 10 & (22) & 9 & (22) & \\
\hline Stage III & 27 & (59) & 22 & (52) & \\
\hline Stage IV & 5 & $(11)$ & 7 & (17) & \\
\hline 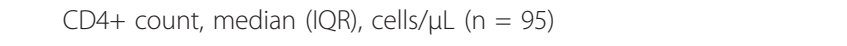 & 147 & $(79,183)$ & 144 & $(100,197)$ & 0.12 \\
\hline Plasma HIV-1 RNA, mean $\left(95 \%\right.$ Cl), $\log _{10}$ copies/ml $(n=92)$ & 4.94 & $(4.70,5.18)$ & 5.15 & $(4.97,5.33)$ & 0.16 \\
\hline HSV-2 seropositive & 44 & $(94)$ & 46 & (96) & 0.68 \\
\hline HAART regimen & & & & & 0.11 \\
\hline AZT/3TC/efavirenz & 29 & (62) & 24 & (50) & \\
\hline d4T/3TC/nevirapine & 10 & (22) & 12 & (25) & \\
\hline d4T/3TC/efavirenz & 3 & (6) & 10 & (21) & \\
\hline AZT/3TC/nevirapine & 3 & (6) & 1 & (2) & \\
\hline AZT/3TC/nelfinavir & 2 & (4) & 0 & (0) & \\
\hline AZT/3TC/indinavir-ritonavir & 0 & (0) & 1 & (2) & \\
\hline
\end{tabular}

NOTE: Data are the no. (\%) of women, unless otherwise indicated.

AZT, zidovudine; d4T, stavudine; 3TC, lamivudine; HAART, highly active antiretroviral therapy; IQR, interquartile range.

*5 missing values and in 2 patients, WHO clinical stage could not be determined at HAART initiation because of missing data such as weight loss or prior opportunistic diseases.

and death was 3.4 months (IQR, 2.3-10.7 months). The median CD4+ count at HAART initiation was 118 cells/ $\mu \mathrm{l}$ (IQR, 85-195) and 146 cells/ $\mu \mathrm{l}$ (IQR, 93-191) in women who died versus women who survived, respectively $(P=0.95)$. Among the deceased women, two already had AIDS-defining symptoms at HAART initiation visit. Presumptive causes of death were tuberculosis for one woman and wasting syndrome for another, whilst no cause of death could be ascertained for two women in whom no severe event had been recorded in the 6 months prior to death.

\section{Biological outcomes}

The median change in CD4+ count and the percentage of patients with undetectable HIV-1 PVL are presented in Figures 3 and 4. Among FSWs, the median values for CD4+ count reached 234 cells/ $\mu$ l (IQR, 180-327) 6 months after HAART initiation, 306 cells/ $\mu$ (IQR, 249382) after 12 months, and 343 cells/ $\mu$ l (IQR, 230-553) after 36 months. The median cumulative increases in the CD4+ count were 132 cells/ $\mu$ l (IQR, 41-196), 177 cells/ $\mu \mathrm{l}$ (IQR, 105-255), and 230 cells/ $\mu \mathrm{l}$ (IQR, 90-400), at 6,12 , and 36 months, respectively (Figure 3 ). These 


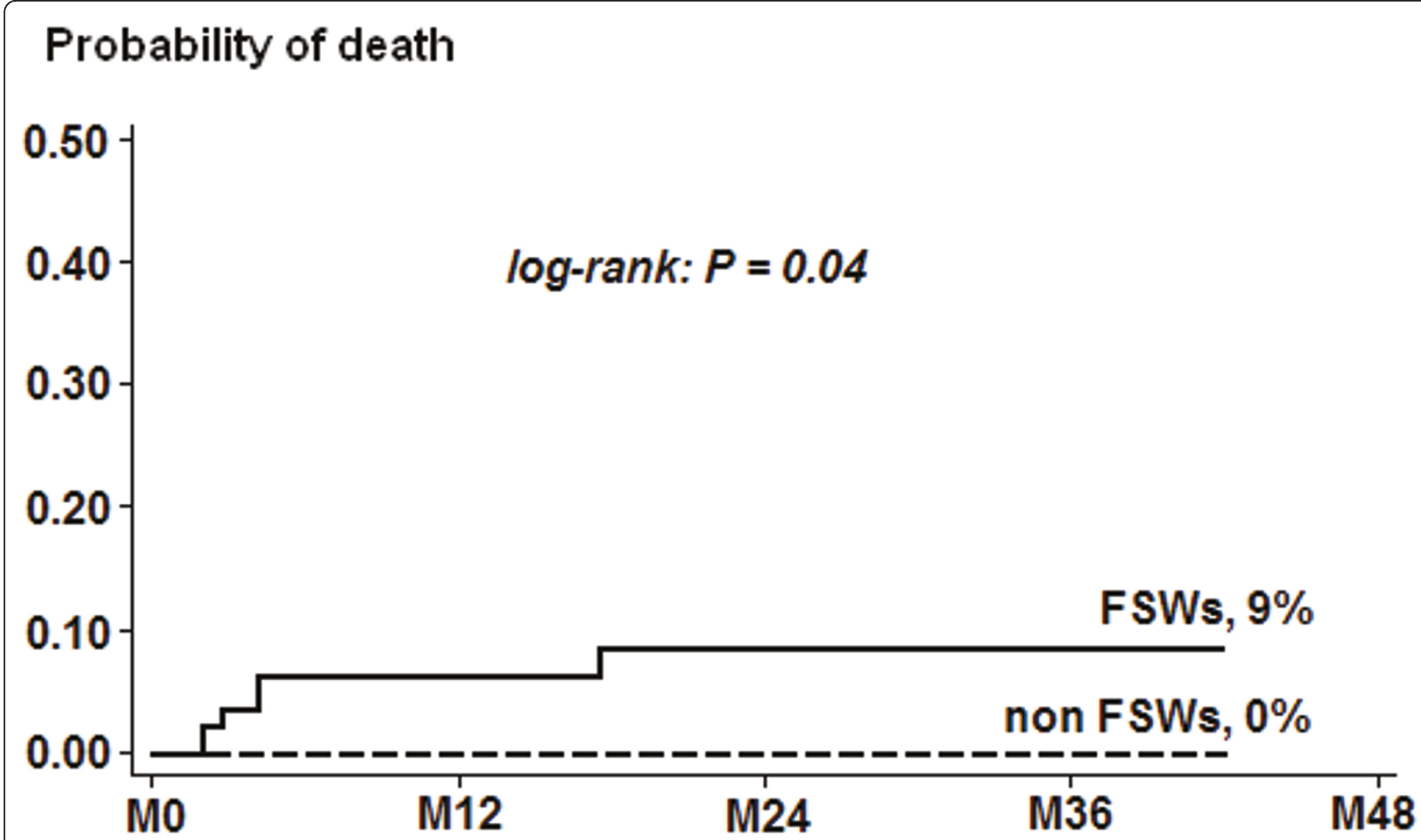

\section{Months of treatment}

Figure 2 Kaplan-Meier curves of cumulative mortality probability among FSWs and non-FSWs receiving HAART in Bobo-Dioulasso, Burkina Faso, 2004-2007.

median CD4+ cell gains were not statistically different from those observed in non-FSWs.

Dynamics of PVL over time after HAART initiation was not statistically different between FSWs and nonFSWs beyond the first 6-month period on HAART (Figure 4). However, over the whole follow-up period, the rate of virological success was $76.7 \%$ (95\% CI, 61.488.2) among FSWs and 95.5\% (95\% CI, 84.5-99.4) among non-FSWs $(P=0.01)$. The rate of primary virological failure at 6 months was 20.6\% (95\% CI, 8.737.9) among FSWs and 2.8\% (95\% CI, 0.1-14.5) among non-FSWs $(P=0.03)$. Secondary virological failures occurred in three women $(5.3 \%, 95 \% \mathrm{CI}, 1.1-14.6)$, including two FSWs.

\section{Discussion}

We describe the long-term mortality and efficacy of HAART in one of the rare longitudinal studies of female sex workers in sub-Saharan Africa. To our knowledge, this is the first report showing that clinical and biological efficacy of HAART can be maintained in the long term in a hard-to-reach, mobile and highly stigmatised population in sub-Saharan Africa.
Follow-up rates were very high in this cohort, including during the first year of treatment, in contrast with a pooled analysis of 5491 adult patients starting HAART in 15 treatment programmes in Africa, Asia and South America [27], in which the scaling-up of HAART programmes was associated with a higher probability of loss to follow-up. This may be explained by the fact that our study was carried out in a clinical research centre, with provision of free care, low numbers of patients, intensive counselling and active tracing of patients, which cannot be representative of all low-resource clinical settings.

Overall, mortality was remarkably low in this study, in contrast with other studies carried out in low-income countries [28-30]. Mortality was higher during the first 3 months following HAART initiation, as reported in similar settings, albeit at even higher levels [28,31-34].

Despite relatively low CD4+ counts at HAART initiation, the long term virological, immunological and clinical responses to HAART among FSWs were broadly comparable to previous reports obtained in general population cohorts of HIV-infected individuals in industrialized countries [35] and in sub-Saharan African settings with relatively low patients numbers and intensive 


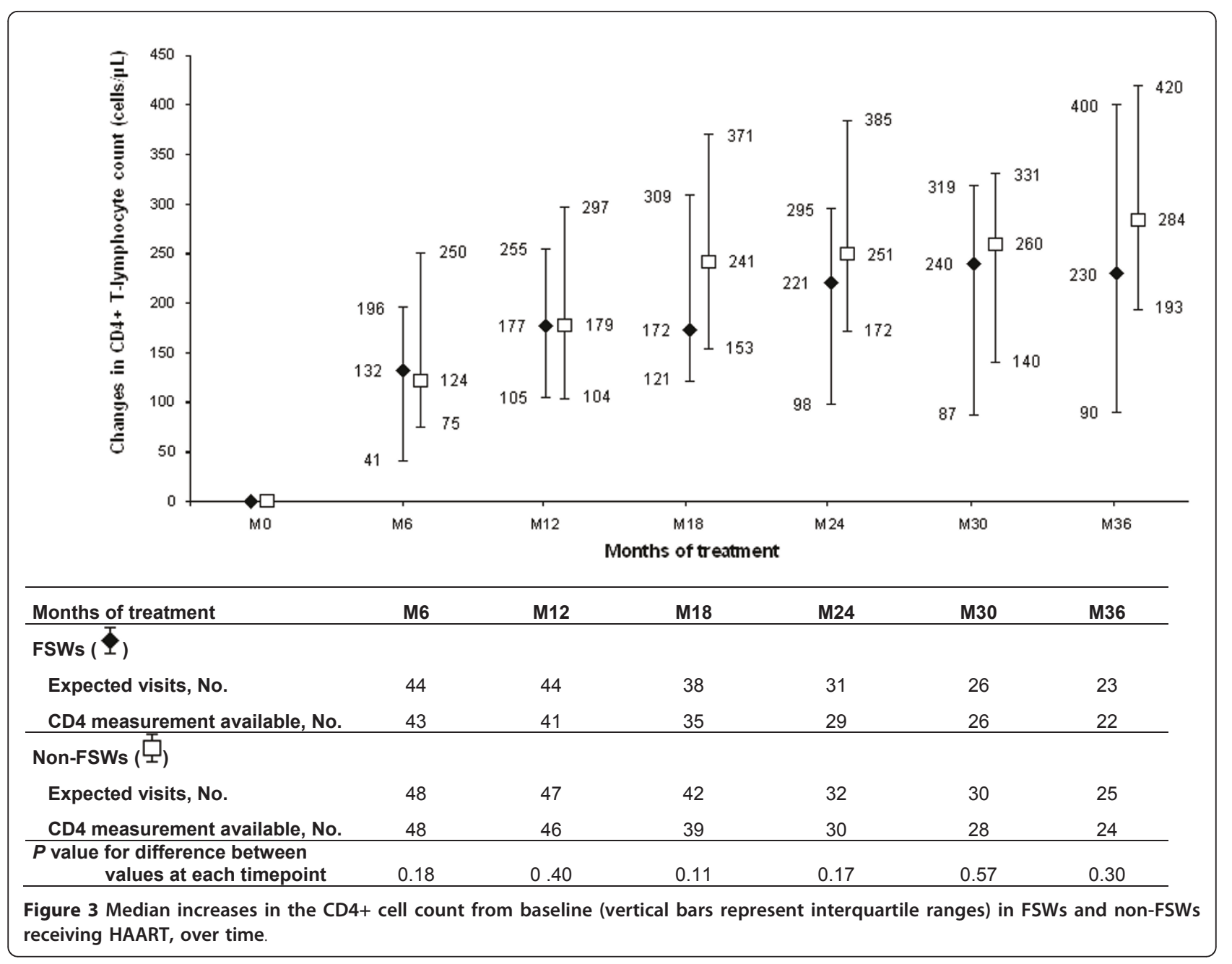

follow-up procedures [1-3,36]. However, within our cohort, FSWs had an apparently less favourable virological response to HAART than non-FSWs. This can not readily be explained by more advanced disease at baseline, higher HIV-1 plasma viral loads, or different HSV2 seroprevalence - an infection known to potentially enhance HIV-1 replication and disease progression [37]. A higher rate of HIV-1 super-infection among sex workers [38] or higher levels of acquired HIV-1 resistant strains, as indicated by the higher rates of primary virological failure observed in FSWs may be possible explanations which would warrant further investigations. Despite similar levels of support, the lower adherence in FSWs, although not statistically significant, but perhaps compounded by higher alcohol use, may also explain the trend for higher rate of primary virological failures in this group.

Our study shows, however, that high levels of adherence to HAART can be achieved and maintained beyond the initial period of clinical benefits among
FSWs, even if some reporting bias may have occurred. Strong support measures that included close follow-up with an outreach team and a peer-educator-based organization, a specific adherence support provided by peereducators, physicians, nurses and psychologists on a monthly basis were certainly central to this achievement. Because FSWs often experience broken down familial and social relationships, we strongly advocate for a specific multidisciplinary approach to adherence support. We also believe that building trustful, respectful and non-judgmental relationships between FSWs and health care workers is crucial. For example, we tried to decrease stigma and discrimination by following FSWs and non-FSWs together at the same clinic.

In this West African setting, HAART regimens containing mainly zidovudine (or stavudine), lamivudine and efavirenz demonstrated good safety and tolerance. The reported adverse events were within the range, both for type and frequency, of those previously reported in similar settings $[2,39]$. Our data confirm the good safety 


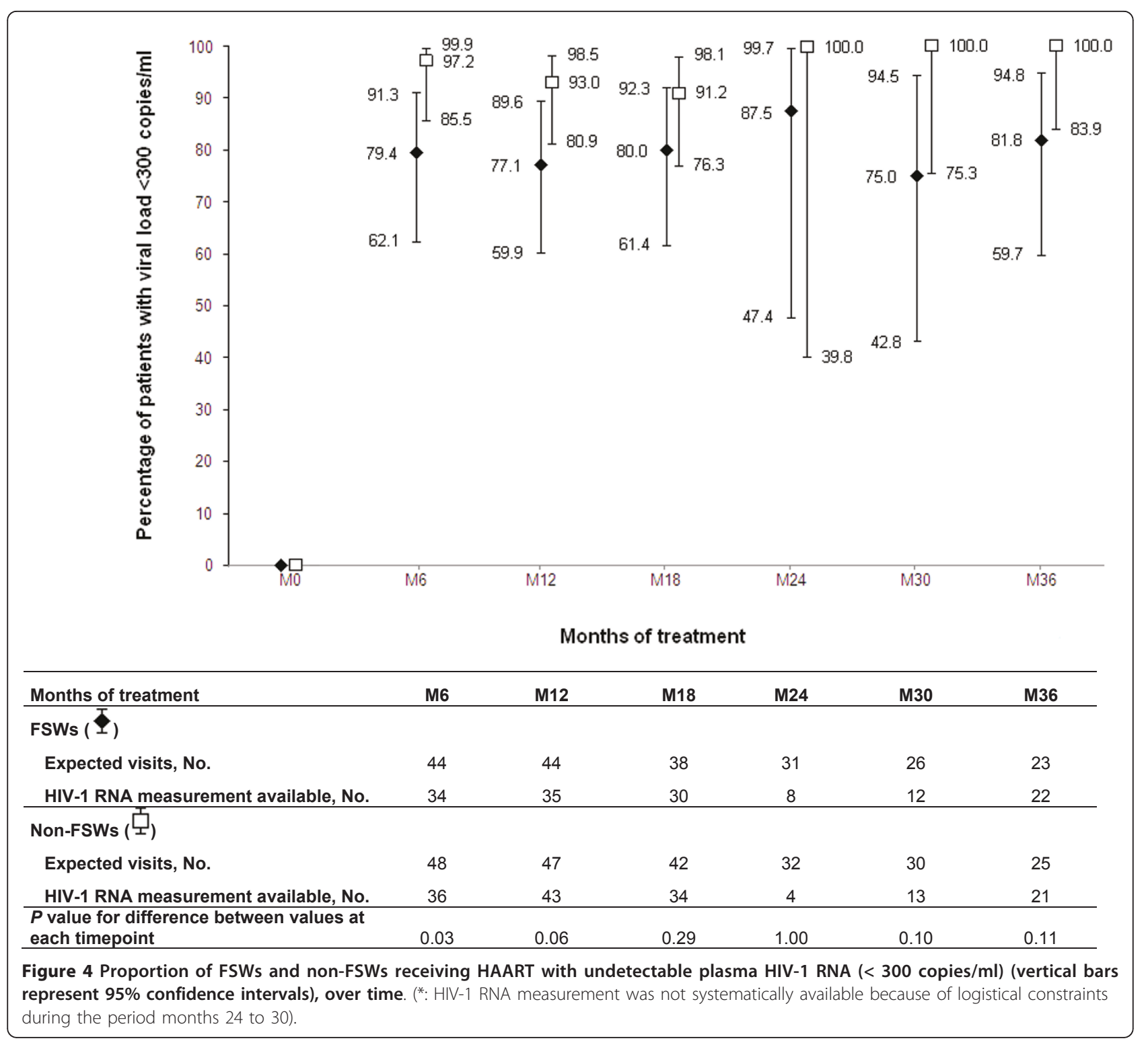

profile of zidovudine in a region with endemic malaria and high risk of anemia.

Our study had a number of limitations. First, our sample size was small, and whilst it allowed for reasonably precise estimates of outcomes, it may not have allowed for identification of small differences in HAART response between the FSW and non-FSW groups. Second, this FSW population cannot be taken to be representative of other FSW populations. Clearly, their risk behaviour at the time of HAART initiation was markedly different from that at time of cohort enrolment [12]. This may be attributed to any combination of (i) the effect of other behavioural interventions provided by the study team, (ii) a modification of behaviour as women perhaps became sicker, (iii) answers motivated by strong social desirability, and (iv) the bias inherent to any long term cohort studies, whereby participants are progressively selected towards more compliant and lower risk individuals. Third, some HIV-1 PVL measurements were missing during the period of 24 and 30 months after HAART initiation, though not after 36 months. This is a result of both logistical difficulties to obtain PVL at one period of the survey, and of our study design, as women recruited late in the cohort did not have any follow-up beyond 24-30 months. Fourth, we could not perform HIV resistance testing. While we might anticipate a low rate of emergence of resistant strains given the good virological responses, it will be important to monitor both primary and secondary resistance to antiretrovirals because of the public health 
implications of dissemination of HIV-resistant strains from a core group [40,41]. It appears also important to determine the cause of primary virological failures in this group of highly exposed women. Finally, our results may not be generalizable to populations with fewer resources and less intense follow-up and counselling such as would be typical during scaled-up programmes.

The potential impact of HAART on HIV-1 sexual transmission was not determined directly during this study, but it is important to consider in core groups. Future modelling studies should include data from settings where core groups have much higher HIV prevalence than the general population and thus may play a key role in HIV transmission dynamics, and data from the effect of HAART on sexual behaviour in these groups.

\section{Conclusions}

HAART becomes an increasingly attractive health investment even in settings with limited resources [42]. We have shown that introducing HAART into hard-toreach and marginalised populations was feasible and that the clinical and biological benefits could be maintained over long periods, which could lead to important public health benefits.

\footnotetext{
Acknowledgements

We thank the women and the organizations of people living with HIV/AIDS (Yerelon, Espoir et Vie, Centre Solidarité Action sociale, and Espoir pour Demain) who participated in this study, and the staff at Service d'Hygiène, and other personnel of Projet Yerelon in Bobo-Dioulasso. We are grateful to the French Agency for AIDS Research (ANRS) and particularly to Brigitte Bazin, Claire Rekacewicz, and Jean-François Delfraissy (director). This study was funded by the French Agence Nationale de Recherches sur le SIDA et les hépatites (ANRS). Additional support was provided by the UK Department for International Development (DFID) Research Programme Consortium on Sexual \& Reproductive Health and HIV of the London School of Hygiene \& Tropical Medicine.
}

\section{Author details}

'Centre Muraz, Bobo-Dioulasso, Burkina Faso. ${ }^{2}$ London School of Hygiene \& Tropical Medicine (LSHTM), London, UK. ${ }^{3}$ INSERM U1058, University Montpellier 1, and CHU Montpellier, France.

\section{Authors' contributions}

$\mathrm{NN}, \mathrm{PM}, \mathrm{PVP}, \mathrm{AO}$, and $\mathrm{CH}$ designed and supervised the study. $\mathrm{AO}, \mathrm{NN}$, and $\mathrm{CH}$ implemented the study with $\mathrm{IK}, \mathrm{IT}$, and AS. Laboratory analyses were conducted by FR and AK. PM and NN advised on the statistical analyses, which were done by $\mathrm{CH}$. CH wrote the first draft of the paper, which was subsequently revised by NN, PM, PVP, and FR. All authors reviewed and approved the final version of the manuscript.

\section{Competing interests}

The authors declare that they have no competing interests.

Received: 25 August 2010 Accepted: 14 September 2011 Published: 14 September 2011

\section{References}

1. Djomand G, Roels T, Ellerbrock T, Hanson D, Diomande F, Monga B, Maurice C, Nkengasong J, Konan-Koko R, Kadio A, Wiktor S, Lackritz E, Saba J, Chorba T: Virologic and immunologic outcomes and programmatic challenges of an antiretroviral treatment pilot project in Abidjan, Cote d'Ivoire. AIDS 2003, 17(Suppl 3):S5-15.

2. Seyler C, Anglaret X, Dakoury-Dogbo N, Messou E, Toure S, Danel C, Diakite N, Daudie A, Inwoley A, Maurice C, Tonwe-Gold B, Rouet F, N'DriYoman T, Salamon R: Medium-term survival, morbidity and immunovirological evolution in HIV-infected adults receiving antiretroviral therapy, Abidjan, Cote d'Ivoire. Antivir Ther 2003, 8:385-393.

3. Laurent C, Ngom Gueye NF, Ndour CT, Gueye PM, Diouf M, Diakhate N, Toure Kane NC, Laniece I, Ndir A, Vergne L, Ndoye I, Mboup S, Sow PS, Delaporte E: Long-term benefits of highly active antiretroviral therapy in Senegalese HIV-1-infected adults. J Acquir Immune Defic Syndr 2005, 38:14-17.

4. Boileau C, Nguyen VK, Sylla M, Machouf N, Chamberland A, Traore HA, Niamba PA, Diallo I, Maiga M, Cisse M, Rashed S, Tremblay C: Low prevalence of detectable HIV plasma viremia in patients treated with antiretroviral therapy in Burkina Faso and Mali. J Acquir Immune Defic Syndr 2008, 48(4):476-484.

5. Granich RM, Gilks CF, Dye C, De Cock KM, Williams BG: Universal voluntary HIV testing with immediate antiretroviral therapy as a strategy for elimination of HIV transmission: a mathematical model. Lancet 2009, 373(9657):48-57.

6. Ouedraogo A, Nagot N, Vergne L, Konate I, Weiss HA, Defer MC, Foulongne V, Sanon A, Andonaba JB, Segondy M, Mayaud P, Van de Perre P: Impact of suppressive herpes therapy on genital HIV-1 RNA among women taking antiretroviral therapy: a randomized controlled trial. AlDS 2006, 20:2305-2313.

7. Wilson DP, Law MG, Grulich AE, Cooper DA, Kaldor JM: Relation between HIV viral load and infectiousness: a model-based analysis. Lancet 2008, 372:314-320.

8. Modjarrad K, Chamot E, Vermund SH: Impact of small reductions in plasma HIV RNA levels on the risk of heterosexual transmission and disease progression. AIDS 2008, 22:2179-2185.

9. Fideli US, Allen SA, Musonda R, Trask S, Hahn BH, Weiss H, Mulenga J, Kasolo F, Vermund SH, Aldrovandi GM: Virologic and immunologic determinants of heterosexual transmission of human immunodeficiency virus type 1 in Africa. AIDS Res Hum Retroviruses 2001, 17:901-910.

10. Quinn TC, Wawer MJ, Sewankambo N, Serwadda D, Li C, WabwireMangen F, Meehan MO, Lutalo T, Gray RH: Viral load and heterosexual transmission of human immunodeficiency virus type 1. Rakai Project Study Group. N Engl J Med 2000, 342:921-929.

11. De Cock KM, Gilks CF, Lo YR, Guerma T: Can antiretroviral therapy eliminate HIV transmission? Lancet 2009, 373(9657):7-9.

12. Nagot N, Ouangre A, Ouedraogo A, Cartoux M, Huygens P, Defer MC, Zekiba T, Meda N, Van de Perre P: Spectrum of commercial sex activity in Burkina Faso: classification model and risk of exposure to HIV. J Acquir Immune Defic Syndr 2002, 29:517-521.

13. Alary M, Lowndes CM: The central role of clients of female sex workers in the dynamics of heterosexual HIV transmisson in sub-Saharan Africa. AIDS 2004, 18:945-947.

14. Morison L, Weiss HA, Buve A, Carael M, Abega SC, Kaona F, Kanhonou L, Chege J, Hayes RJ: Commercial sex and the spread of HIV in four cities in sub-Saharan Africa. Aids 2001, 15(Suppl 4):S61-69.

15. Cote AM, Sobela F, Dzokoto A, Nzambi K, Asamoah-Adu C, Labbe AC, Masse B, Mensah J, Frost E, Pepin J: Transactional sex is the driving force in the dynamics of HIV in Accra, Ghana. AIDS 2004, 18:917-925.

16. Alary M, Mukenge-Tshibaka L, Bernier F, Geraldo N, Lowndes CM, Meda H, Gnintoungbe CA, Anagonou S, Joly JR: Decline in the prevalence of HIV and sexually transmitted diseases among female sex workers in Cotonou, Benin, 1993-1999. AIDS 2002, 16:463-470.

17. Ghys PD, Diallo MO, Ettiegne-Traore V, Kale K, Tawil O, Carael M, Traore M, Mah-Bi G, De Cock KM, Wiktor SZ, Laga M, Greenberg AE: Increase in condom use and decline in HIV and sexually transmitted diseases among female sex workers in Abidjan, Cote d'Ivoire, 1991-1998. AIDS 2002, 16:251-258.

18. Nagot N, Ouedraogo A, Ouangre A, Cartoux M, Defer MC, Meda N, Van de Perre $P$ : Is sexually transmitted infection management among sex workers still able to mitigate the spread of HIV infection in West Africa? J Acquir Immune Defic Syndr 2005, 39:454-458.

19. Nagot N, Ouedraogo A, Foulongne V, Konate I, Weiss HA, Vergne L, Defer MC, Djagbare D, Sanon A, Andonaba JB, Becquart P, Segondy M, Vallo R, Sawadogo A, Van de Perre P, Mayaud P: Reduction of HIV-1 RNA 
levels with therapy to suppress herpes simplex virus. N Engl J Med 2007, 356:790-799.

20. World Health Organization: Safe and effective use of antiretroviral treatments in adults with particular reference to resource limited settings. Geneva: WHO/UNAIDS; 2000

21. WHO expert consultation on cotrimoxazole prophylaxis in HIV infection: WHO technical report series. Geneva: WHO; 2006 [http://www.who.int/hiv/ pub/meetingreports/ctx/en], accessed on 27 July 2010.

22. Meda N, Gautier-Charpentier L, Soudre RB, Dahourou H, OuedraogoTraore R, Ouangre A, Bambara A, Kpozehouen A, Sanou H, Valea D, Ky F, Cartoux M, Barin F, Van de Perre P: Serological diagnosis of human immuno-deficiency virus in Burkina Faso: reliable, practical strategies using less expensive commercial test kits. Bull World Health Organ 1999, 77:731-739.

23. Joint United Nations Programme on HIV/AIDS (UNAIDS)-WHO. Revised recommendations for the selection and use of HIV antibody tests. Wkly Epidemiol Rec 1997, 72:81-87.

24. Rouet F, Chaix ML, Nerrienet E, Ngo-Giang-Huong N, Plantier JC, Burgard M, Peeters M, Damond F, Ekouevi DK, Msellati P, Ferradini L, Rukobo S, Marechal V, Schvachsa N, Wakrim L, Rafalimanana C, Rakotoambinina B, Viard JP, Seigneurin JM, Rouzioux C: Impact of HIV-1 genetic diversity on plasma HIV-1 RNA Quantification: usefulness of the Agence Nationale de Recherches sur le SIDA second-generation long terminal repeat-based real-time reverse transcriptase polymerase chain reaction test. J Acquir Immune Defic Syndr 2007, 45:380-388.

25. van Dyck E, Buve A, Weiss HA, Glynn JR, Brown DW, De Deken B, Parry J, Hayes RJ: Performance of commercially available enzyme immunoassays for detection of antibodies against herpes simplex virus type 2 in African populations. J Clin Microbiol 2004, 42(7):2961-2965.

26. Agence Nationale de Recherche sur le Sida et les hépatites virales: Echelle ANRS de Cotation de la Gravité des Evénements Indésirables chez l'adulte., Version no. 6 du 9 septembre 2003.

27. Brinkhof MW, Dabis F, Myer L, Bangsberg DR, Boulle A, Nash D, et al: Early loss of HIV-infected patients on potent antiretroviral therapy programmes in lower-income countries. Bull World Health Organ 2008, 86:559-567.

28. Etard JF, Ndiaye I, Thierry-Mieg M, Gueye NF, Gueye PM, Laniece I, Dieng AB, Diouf A, Laurent C, Mboup S, Sow PS, Delaporte E: Mortality and causes of death in adults receiving highly active antiretroviral therapy in Senegal: a 7-year cohort study. AIDS 2006, 20:1181-1189.

29. Toure S, Kouadio B, Seyler C, Traore M, Dakoury-Dogbo N, Duvignac J, Diakite N, Karcher S, Grundmann C, Marlink R, Dabis F, Anglaret X: Rapid scaling-up of antiretroviral therapy in 10,000 adults in Cote d'Ivoire: 2year outcomes and determinants. AIDS 2008, 22:873-882.

30. Boulle A, Bock P, Osler M, Cohen K, Channing L, Hilderbrand K, Mothibi E, Zweigenthal V, Slingers N, Cloete K, Abdullah F: Antiretroviral therapy and early mortality in South Africa. Bull World Health Organ 2008, 86:678-687.

31. Braitstein P, Brinkhof MW, Dabis F, Schechter M, Boulle A, Miotti P, Wood R, Laurent C, Sprinz E, Seyler C, Bangsberg DR, Balestre E, Sterne JA, May M, Egger M: Mortality of HIV-1-infected patients in the first year of antiretroviral therapy: comparison between low-income and highincome countries. Lancet 2006, 367(9513):817-824.

32. Lawn SD, Harries AD, Anglaret X, Myer L, Wood R: Early mortality among adults accessing antiretroviral treatment programmes in sub-Saharan Africa. AIDS 2008, 22:1897-1908.

33. Marazzi MC, Liotta G, Germano P, Guidotti G, Altan AD, Ceffa S, Lio MM, Nielsen-Saines K, Palombi L: Excessive early mortality in the first year of treatment in HIV type 1-infected patients initiating antiretroviral therapy in resource-limited settings. AIDS Res Hum Retroviruses 2008, 24:555-560.

34. Keiser O, Orrell C, Egger M, Wood R, Brinkhof MW, Furrer H, van Cutsem G, Ledergerber B, Boulle A: Public-health and individual approaches to antiretroviral therapy: township South Africa and Switzerland compared. PLoS Med 2008, 5(7):e148.

35. Egger M, May M, Chene G, Phillips AN, Ledergerber B, Dabis F, Costagliola D, D'Arminio Monforte A, de Wolf F, Reiss P, Lundgren JD, Justice AC, Staszewski S, Leport C, Hogg RS, Sabin CA, Gill MJ, Salzberger B, Sterne JA: Prognosis of HIV-1-infected patients starting highly active antiretroviral therapy: a collaborative analysis of prospective studies. Lancet 2002, 360:119-129.

36. Coetzee D, Hildebrand K, Boulle A, Maartens G, Louis F, Labatala V, Reuter H, Ntwana N, Goemaere E: Outcomes after two years of providing antiretroviral treatment in Khayelitsha, South Africa. AIDS 2004, 18:887-895.

37. Celum C, Levine R, Weaver M, Wald A: Genital herpes and human immunodeficiency virus: double trouble. Bull World Health Organ 2004 82:447-453.

38. Manigart O, Courgnaud V, Sanou O, Valea D, Nagot N, Meda N, Delaporte E, Peeters M, Van de Perre P: HIV-1 superinfections in a cohort of commercial sex workers in Burkina Faso as assessed by an autologous heteroduplex mobility procedure. AIDS 2004, 18:1645-1651.

39. Hoffmann CJ, Fielding KL, Charalambous S, Sulkowski MS, Innes C, Thio CL, Chaisson RE, Churchyard GJ, Grant AD: Antiretroviral therapy using zidovudine, lamivudine, and efavirenz in South Africa: tolerability and clinical events. AIDS 2008, 22:67-74.

40. Hamers RL, Derdelinckx I, van Vugt M, Stevens W, Rinke de Wit TF, Schuurman R: The status of HIV-1 resistance to antiretroviral drugs in sub-Saharan Africa. Antivir Ther 2008, 13:625-639.

41. Tebit DM, Sangare L, Makamtse A, Yameogo S, Somlare H, Bado G, Kouldiaty BG, Sathiandee K, Tiba F, Sanou I, Ouedraogo-Traore R, Zoungrana L, Diallo I, Drabo JY, Krausslich HG: HIV drug resistance pattern among HAART-exposed patients with suboptimal virological response in Ouagadougou, Burkina Faso. J Acquir Immune Defic Syndr 2008, 49:17-25.

42. Goldie SJ, Yazdanpanah Y, Losina E, Weinstein MC, Anglaret X, Walensky RP, Hsu HE, Kimmel A, Holmes C, Kaplan JE, Freedberg KA: Cost-effectiveness of HIV treatment in resource-poor settings-the case of Cote d'Ivoire. N Engl J Med 2006, 355(11):1141-1153.

\section{Pre-publication history}

The pre-publication history for this paper can be accessed here: http://www.biomedcentral.com/1471-2458/11/700/prepub

\section{doi:10.1186/1471-2458-11-700}

Cite this article as: Huet et al: Long term virological, immunological and mortality outcomes in a cohort of HIV-infected female sex workers treated with highly active antiretroviral therapy in Africa. BMC Public Health 2011 11:700

\section{Submit your next manuscript to BioMed Central and take full advantage of:}

- Convenient online submission

- Thorough peer review

- No space constraints or color figure charges

- Immediate publication on acceptance

- Inclusion in PubMed, CAS, Scopus and Google Scholar

- Research which is freely available for redistribution

Submit your manuscript at www.biomedcentral.com/submit
C Biomed Central 